\title{
Amelioration of Doxorubicin Induced Cardiotoxicity in Tumor Bearing Mice by Ferulic Acid: a Mechanistic Study at Cellular and Biochemical Level
}

\author{
Saratchandran A. Divakaran ${ }^{1,2}$, Cherupally Krishnan Krishnan Nair ${ }^{3, *}$ \\ ${ }^{1}$ Amala Cancer Research Centre, 680555, Thrissur \\ ${ }^{2}$ Sree Kerala Varma College, Thrissur, Kerala, 680011, India \\ ${ }^{3}$ Pushpagiri Institute of Medical Sciences \& Research Centre, Thiruvalla Kerala, 689101, India
}

\begin{abstract}
Doxorubicin (DOX) is one of the most effective anticancer therapeutic but its use is limited by cardiotoxicity. The generation of reactive oxygen species (ROS) and mitochondrial dysfunction have been implicated in DOX-induced cardiotoxicity. Cardiotoxicity was induced in tumor bearing mice by a single dose of DOX ( $25 \mathrm{mg} / \mathrm{kg}$, i.p). Ferulic acid (FA) $(100 \mathrm{mg} / \mathrm{kg}$ p.o and $200 \mathrm{mg} / \mathrm{kg}$ p.o $)$ was administered one hour after DOX administration. The administration of FA significantly protected the myocardium from the toxic effects of DOX by reducing the levels of serum marker enzymes like CK and LDH and other serum enzymes SGOT and SGPT, which were elevated during DOX induced cardiomyopathy. The level of HDL was also significantly increased in FA administered groups compared to DOX control. FA protected the cardiac tissues, whereas it potentiated the anticancer efficacy of DOX in tumor tissues as evident from different antioxidant enzyme levels and the extent of lipid peroxidation. The histopathological observations also supported these results. FA effectively protected cellular DNA in heart tissue preferentially, without offering any protection to the DNA in tumour tissues as evidenced from the comet assay. These results suggest that ferulic acid has a protective effect against cardiotoxicity induced by DOX and it may, therefore improve the chemotherapeutic index of DOX.
\end{abstract}

Keywords Cardiotoxicity, Doxorubicin, antioxidant, lipid peroxidation: tumor

\section{Introduction}

Doxorubicin (DOX), an anthracyclin antibiotic, has been found to effective in the treatment of a variety of solid tumors including hemopoietic malignancies in children and adults. However, its use is limited primarily due to cardiotoxicity following an acute dose as well as cumulative doses[1]. The chronic cardiotoxicity is dose-dependent and causes irreversible myocardial damage, resulting in dilated cardiomyopathy with fatal congestive heart failure[2]. The mechanisms proposed for cardiotoxic effects of DOX include free radical induced myocardial injury, membrane lipid peroxidation[3], mitochondrial damage[4], decreased activity of $\mathrm{Na}^{+} \mathrm{K}^{+}$ATPase[5] increase in serum total cholesterol, triglycerides, and low density lipoproteins[6] as well as elevation of serum enzymes like lactate dehydrogenase (LDH) and creatine kinase (CK)[7].

Endogenous antioxidant deficits have been suggested to play a major role in doxorubicin- induced cardiotoxicity. Due to the presence of less developed antioxidant defence

* Corresponding author:

ckknair@yahoo.com (Cherupally Krishnan Krishnan Nair)

Published online at http://journal.sapub.org/ijit

Copyright (C) 2012 Scientific \& Academic Publishing. All Rights Reserved mechanisms, heart is particularly vulnerable to injury by anthracycline - induced reactive oxygen species[8]. Antioxidants have been reported to have beneficial effects against DOX-induced cardiotoxicity in mice and rats[9] as they protect cells and tissues from free radicals induced oxidative damage and injury[10].

The present study envisages exploring the effect of ferulic acid (FA) or 4-Hydroxy-3-Methoxycinnamic Acid (Fig.1) on DOX- induced cardio toxicity in tumor bearing Swiss albino mice. Phenolics are widely distributed in the plant kingdom and are integral part of human diet[11]. As an antioxidant, FA play a major role in the body's defense against carcinogenesis by inhibiting the formation of $\mathrm{N}$-nitroso compounds[12]. Moreover, FA is a strong scavenger of free radicals and it has been approved in certain countries as food additive to prevent lipid peroxidation[13]. FA possesses radioprotective abilities and reduces ionizing radiation induced damages to DNA and membranes in biological systems[14].<smiles>COc1cc(/C=C/C(=O)O)ccc1O</smiles>

Figure 1. Ferulic acid (FA) 


\section{Materials and Methods}

\subsection{Animals}

Female Swiss albino mice, 6-8-weeks old (body weight 25-30 g), were kept under standard conditions of temperature $\left(25 \pm 5^{\circ} \mathrm{C}\right)$ and humidity in the Centre's Animal House Facility. The animals were provided with standard mouse chow (Sai Durga Feeds and Foods, Bangalore, India) and water ad libitum. All experiments in this study were carried out with the prior approval of the Institutional Animal Ethics Committee (IAEC) and were conducted strictly adhering to the guidelines of Committee for the Purpose of Control and Supervision of Experiments on Animals (CPCSEA) constituted by the Animal Welfare Division of Government of India.

\subsection{Chemicals}

Ferulic acid (FA), Nitroblue tetrazolium (NBT), riboflavin, reduced glutathione (GSH), 5-5' dithiobis-2- nitro benzoic acid (DTNB) were purchased from Sigma Chemical Company Inc., St. Louis, MO, USA. Doxorubicin (DOX) was purchased from Cadila pharmaceuticals Ltd., Oncocare Division, Ahmedabad, India. EDTA was from Sisco Research Laboratories Pvt. Ltd., Mumbai, India. $\mathrm{H}_{2} \mathrm{O}_{2}$ was from Merck India Ltd., Mumbai, India. Thiobarbituric acid (TBA) was purchased from Hi-media Laboratories, Mumbai, India. All other chemicals and reagents used in this study were of analytical grade procured from reputed Indian manufacturers.

\subsection{Administration of Drugs}

Doxorubicin was administered intraperitoneally as a single dose of $25 \mathrm{mg} / \mathrm{kg}$ b.w. Ferulic acid dissolved in distilled water was given to animals using oral gavage at doses of 100 $\mathrm{mg} / \mathrm{kg}$ and $200 \mathrm{mg} / \mathrm{kg}$.

Solid tumor in Animals- Solid tumor was developed in hind limbs of mice by transplanting Dalton's Lymphoma Ascites (DLA) cells $\left(1 \times 10^{6}\right.$ cells/animal $)$ through subcutaneous injection. The animals were provided with standard mouse chow and water ad libitum. The treatments were started when the tumor size reached approximately $1.0 \mathrm{~cm}^{3}$ on the 13th day of transplantation of DLA cells. The animals were randomly divided into 4 groups of five each and treated as follows.

Group - I untreated control group $(0.1 \mathrm{ml}$ saline i.p and 0.1 $\mathrm{ml}$ distilled water p.o.)

Group - II DOX control, doxorubicin $25 \mathrm{mg} / \mathrm{kg}$ b.w (in 0.1 $\mathrm{ml}$ saline i.p as single dose).

Group - III Doxorubicin 25mg/kg b.w (in $0.1 \mathrm{ml}$ saline i.p as single dose) + Ferulic acid $100 \mathrm{mg} / \mathrm{kg} \mathrm{b.w} \mathrm{(in} 0.1 \mathrm{ml}$ distilled water p.o).

Group - IV Doxorubicin $25 \mathrm{mg} / \mathrm{kg}$ b.w (in $0.1 \mathrm{ml}$ saline i.p as single dose) + Ferulic acid $200 \mathrm{mg} / \mathrm{kg}$ b.w (in $0.1 \mathrm{ml}$ distilled water p.o).

Ferulic acid was administered to Group III and IV animals, one hour after DOX ( $25 \mathrm{mg} / \mathrm{kg}$ b.w) administration.

\subsection{Assessment of Toxicity on Heart and Tumor Tissues}

The toxicity to cardiac and tumor tissues were monitored by histopathological examinations, alteration in biochemical parameters and cellular DNA damage in animals administered with the drugs either alone or in combination. From the animals of different groups, the blood was collected by direct cardiac puncture under light ether anesthesia following $24 \mathrm{hs}$ of various treatment as described above and serum was separated for the biochemical estimations. The heart and tumor tissues were dissected, from each group and were taken for histopathological examination. Single cell suspensions of the tissues prepared in $0.1 \mathrm{M}$ phosphate buffer (pH.7) $\left(10^{6} \mathrm{cells} / \mathrm{ml}\right)$ were used to perform comet assay (Alkaline single cell gel electrophoresis).

Biochemical parameters such as creatine kinase (CK) lactate dehydrogenase (LDH), serum glutamate oxaloacetate transaminase (SGOT), serum glutamate pyruvate transaminase (SGPT) and high density lipoprotein (HDL) were analyzed as cardiac biomarkers using diagnostic kits (Agappe Diagnostic Pvt. Ltd., Thane, India). The oxidative damage in cardiac and tumor tissues following various treatments were estimated by monitoring superoxide dismutase (SOD)[15], glutathione peroxidase $(\mathrm{GPx})[16]$, reduced glutathione (GSH)[17] and for lipid peroxidation (LPO)[18] in 10\% homogenates of the tissues in PBS.

For histopathological studies, tissues were fixed in $10 \%$ formalin and embedded in paraffin wax. Sections of $5 \mathrm{mi}-$ cron thickness were made using a microtome and stained with haematoxylin-eosin. The histopathological examinations were carried out at Sudharma Metropolis Pathological Laboratory, Thrissur, Kerala, India.

\subsection{Estimation of Cellular DNA Damage in Heart and Tumor Tissues by Comet Assay (Alkaline Single Cell Gel Electrophoresis)}

Administration of doxorubicin to animals causes oxidative stress in the tissues, which in turn cause damage to cellular DNA. The damage in cellular DNA following various treatments were estimated by alkaline comet assay or single cell gel electrophoresis as DNA single strand breaks in heart and tumor tissues. Alkaline single cell gel electrophoresis was performed by modified method of Chandrasekharan et al.[19]. Microscopic slides were coated with $200 \mu \mathrm{l}$ of $0.8 \%$ low melting point agarose containing $50 \mu \mathrm{l}$ of cell suspensions and the slides were incubated at $4{ }^{\circ} \mathrm{C}$. After solidification, the slides were immersed in pre-chilled lysing solution containing $2.5 \mathrm{M} \mathrm{NaCl}, 100 \mathrm{mM} \mathrm{Na} 2$ EDTA, $10 \mathrm{mM}$ Tris-HCl, pH 10, 1\% DMSO, $1 \%$ Triton $\mathrm{X}$ and incubated for $1 \mathrm{hr}$ at $4^{\circ} \mathrm{C}$. After lysis, slides were drained properly and placed in a horizontal electrophoretic apparatus filled with freshly prepared electrophoresis buffer containing $300 \mathrm{mM}$ $\mathrm{NaOH}, 1 \mathrm{mM}$ EDTA, $0.2 \% \mathrm{DMSO}, \mathrm{pH} \geq 13$. The slides were equilibrated in buffer for 20 minutes and electrophoresis was carried out for 30 minutes at $20 \mathrm{~V}, 300 \mathrm{~mA}$. After electrophoresis the slides were washed gently with $0.4 \mathrm{mM}$ Tris-HCl buffer, $\mathrm{pH}-7.4$ to remove alkali. The slides were 
again washed with distilled water, incubated at $37^{\circ} \mathrm{C}$ for $2 \mathrm{hs}$ to dry the gel and silver staining was carried out[20]. The comets were visualized using a microscope and the images captured were analyzed using the software 'CASP' which gives \% DNA in tail, tail length, tail moment and olive tail moment directly. The parameter, tail moment (TM) is the product of tail length and \% DNA in tail and olive tail moment (OTM) is the product of the distance between the centre of the head and the centre of the tail and \% DNA in tail[21,22].

\subsection{Statistical Analysis}

The results are presented as Mean \pm SD of the studied group. Statistical analyses of the results were performed using ANOVA with Tukey-Kramer multiple comparisons test.

\section{Results}

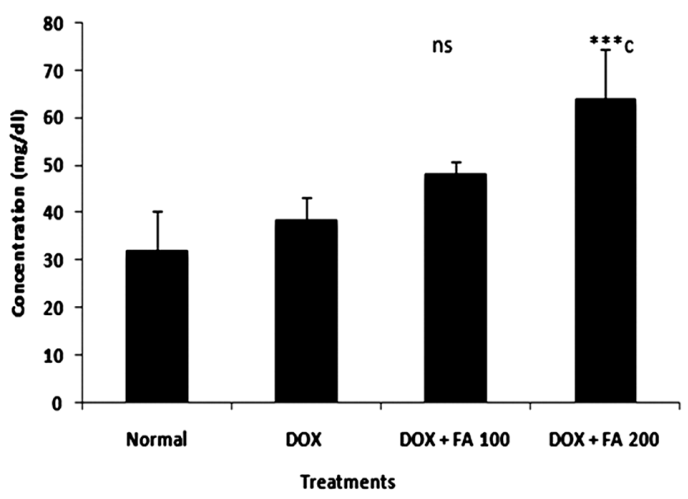

Figure 2. Effect of administration of ferulic acid $(100 \mathrm{mg} / \mathrm{kg}$ and $200 \mathrm{mg} / \mathrm{kg}$ ) on HDL level in doxorubicin induced cardiotoxicity. (ns indicate not significant and $* * *$ indicate $\mathrm{p}<0.001$ when compared with DOX alone treated group)

\subsection{Serum Enzyme Levels}

Animals treated with DOX produced significant increase in the levels of serum enzyme levels (Table.1). A single i.p injection of DOX significantly elevated serum SGOT, SGPT, $\mathrm{CK}$ and $\mathrm{LDH}$ levels from $227.48 \pm 53.61 \mathrm{U} / \mathrm{L}, 49.41 \pm 6.45$ $\mathrm{U} / \mathrm{L}, 65 \pm 12.98 \mathrm{U} / \mathrm{L}$ and $297.63 \pm 39.58 \mathrm{U} / \mathrm{dL}$ to $4510 \pm 842.93$ $\mathrm{U} / \mathrm{L}, 156 \pm 11.52 \mathrm{U} / \mathrm{L}, 425.66 \pm 102.76 \mathrm{U} / \mathrm{L}$ and $3598.86 \pm$
618.15 U/dL respectively, indicative of cardio toxicity. The post treatment with FA (100 mg/kg b.w and $200 \mathrm{mg} / \mathrm{kg} \mathrm{b.w})$ in tumor bearing animals significantly ameliorated SGOT, SGPT, LDH and CK enzyme activities in a dose dependent manner. Treatments with FA to DOX-challenged animals significantly decreased $(p<0.001)$ the activities of these enzymes elevated by doxorubicin, though not to normal. Animals treated with DOX produced slight difference in HDL levels compared to untreated control. The administration of DOX and FA (200mg/Kg b.w) caused significant increase in the level of HDL as compared to DOX control (Fig. 2).

\subsection{Biochemical Measurements and Antioxidant Status}

MDA (Malondialdehyde) was measured as a marker of lipid peroxidation and an indicator of oxidative injury. The MDA levels in heart tissue were increased significantly in the DOX treated group compared with the untreated control group. The increase in MDA by DOX was significantly attenuated by the administration of FA (Fig. 3). Different antioxidant enzymes were examined in the heart tissue from all the groups. The DOX-treated mice showed a significant decrease in SOD, GPX and GSH activities compared with the untreated control (Table. 2). The decrease in activities of SOD, GPX and GSH due to doxorubicin was attenuated by FA.

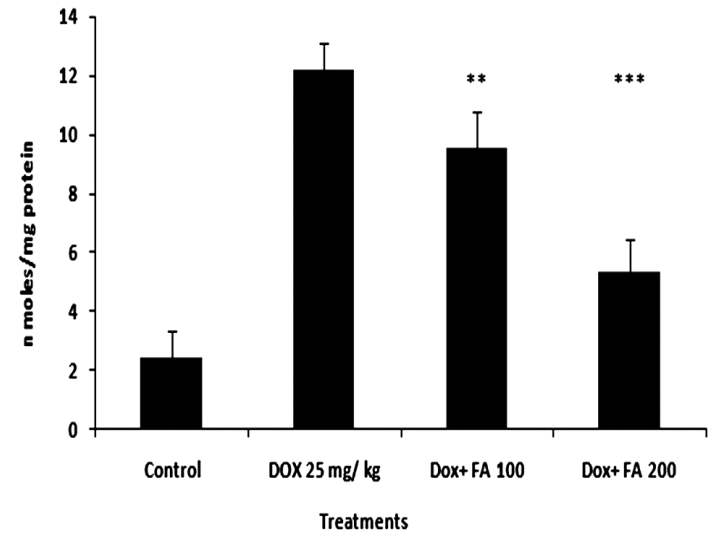

Figure 3. Effect of administration of ferulic acid on doxorubicin- induced lipid peroxidation (MDA formation) in heart tissues of mice. $(* *$ indicate $\mathrm{p}<0.01$ and $* * *$ indicate $\mathrm{p}<0.001$ when compared with the DOX alone treated group)

Table 1. Effect of ferulic acid on serum marker enzymes in doxorubicin induced cardio toxicity in mice. values are expressed as mean \pm sd $(\mathrm{n}=5$ ). Data were analyzed by using one-way anova followed by Tukey multiple comparison test. ' $\mathrm{a}$ ' represents $\mathrm{p}<0.001 \mathrm{vs} \mathrm{DOX}$ control.

\begin{tabular}{|c|c|c|c|c|}
\hline Treatment & SGOT (U/L) & CK (U/L) & LDH(U/dl) & SGPT(U/L) \\
\hline Control & $227.48 \pm 53.61$ & $65 \pm 12.98$ & $297.63 \pm 39.58$ & $49.41 \pm 6.45$ \\
\hline DOX (25mg/ kg) & $4510 \pm 842.93$ & $425.66 \pm 102.76$ & $3598.86 \pm 618.15$ & $156 \pm 11.52$ \\
\hline DOX +FA (100 mg/ kg) & $1650 \pm 588.64^{\mathrm{a}}$ & $263.77 \pm 15.6^{\mathrm{a}}$ & $2609.28 \pm 206.7^{\mathrm{a}}$ & $72 \pm 6.22^{\mathrm{a}}$ \\
\hline DOX +FA (200 mg/ kg) & $1272.44 \pm 337.04^{\mathrm{a}}$ & $153.3 \pm 11.23^{\mathrm{a}}$ & $1725.64 \pm 205.27^{\mathrm{a}}$ & $62.62 \pm 12.12^{\mathrm{a}}$ \\
\hline
\end{tabular}

Table 2. Effect of post administration of FA on doxorubicin induced depletion of GPx, GSH, and SOD levels in heart tissue of tumor bearing mice. Values are expressed as mean $\pm \mathrm{sd}(\mathrm{n}=5)$. Data were analyzed by using one-way anova followed by Tukey multiple comparison test. ' $\mathrm{a}$ ' represent $\mathrm{p}<0.01$ vs $\mathrm{DOX}$ control; ' $b$ ' represent $\mathrm{p}<0.001$ vs DOX control

\begin{tabular}{|c|c|c|c|}
\hline Treatment & GPx(Unit/mg protein) & GSH (n moles/mg protein) & SOD (Unit/mg protein) \\
\hline Control & $40.98 \pm 4.99$ & $27.46 \pm 2.45$ & $1.41 \pm 0.01$ \\
\hline DOX (25mg/ kg) & $22.96 \pm 2.82$ & $11.17 \pm 0.32$ & $0.32 \pm 0.06$ \\
\hline DOX +FA (100 mg/kg) & $31.28 \pm 4.11^{\mathrm{a}}$ & $14.57 \pm 1.89^{\mathrm{a}}$ & $0.54 \pm 0.18^{\mathrm{a}}$ \\
\hline DOX +FA (200 mg/ kg) & $34 . \pm 2.17^{\mathrm{b}}$ & $18.82 \pm 1.02^{\mathrm{b}}$ & $0.91 \pm 0.05^{\mathrm{b}}$ \\
\hline
\end{tabular}


In tumor tissues the MDA levels were increased significantly in the DOX treated group compared with the untreated control group. The post administration of FA along with DOX effectively potentiated the formation of MDA in a significant manner (Fig.4). The antioxidant enzymes such as GPx, SOD and GSH activities in the tumor tissues were significantly reduced in the DOX and ferulic acid treated group when compared to the respective control (Table. 3).

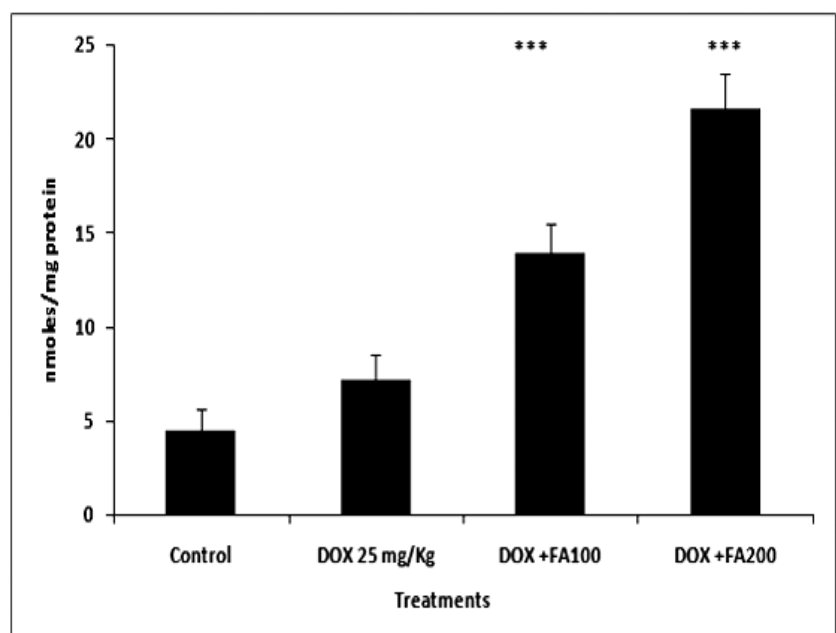

Figure 4. Effect of administration of Ferulic acid on doxorubicin- induced lipid peroxidation (MDA formation) in tumor tissues of mice. (*** indicate $\mathrm{p}<0.001$ when compared with the DOX alone treated group).

Table 3. Effect of p.o administration of ferulic acid on doxorubicin induced depletion of GPx, GSH and SOD levels in tumor tissues of mice. values are expressed as mean \pm sd $(n=5)$. Data were analyzed by using one-way anova followed by Tukey multiple comparison test. ' $a$ ' represen $p<0.01$ vs DOX control ; ' $b$ ' represent $p<0.001$ vs DOX control ; 'c'represent $\mathrm{p}<0.05$ vs DOX control

\begin{tabular}{|c|c|c|c|}
\hline Treatment & $\begin{array}{c}\text { GPx (Unit/mg } \\
\text { protein) }\end{array}$ & $\begin{array}{c}\text { GSH (n } \\
\text { moles/mg } \\
\text { protein) }\end{array}$ & $\begin{array}{c}\text { SOD } \\
\text { (Unit/mg } \\
\text { protein) }\end{array}$ \\
\hline Control & $27.83 \pm 3.42$ & $19.74 \pm 1.86$ & $4.016 \pm 0.10$ \\
\hline DOX(25mg/ kg) & $22.46 \pm 2.97$ & $16.63 \pm 0.89$ & $2.58 \pm 0.68$ \\
\hline $\begin{array}{c}\mathrm{DOX}+\mathrm{FA} \\
(100 \mathrm{mg} / \mathrm{kg})\end{array}$ & $16.16 \pm 2.67^{\mathrm{a}}$ & $13.75 \pm 1.83^{\mathrm{c}}$ & $1.85 \pm 0.28^{\mathrm{c}}$ \\
\hline $\begin{array}{c}\mathrm{DOX}+\mathrm{FA} \\
(200 \mathrm{mg} / \mathrm{kg})\end{array}$ & $14.5 \pm 2.76^{\mathrm{b}}$ & $11.44 \pm 1.69^{\mathrm{b}}$ & $1.24 \pm 0.19^{\mathrm{b}}$ \\
\hline
\end{tabular}
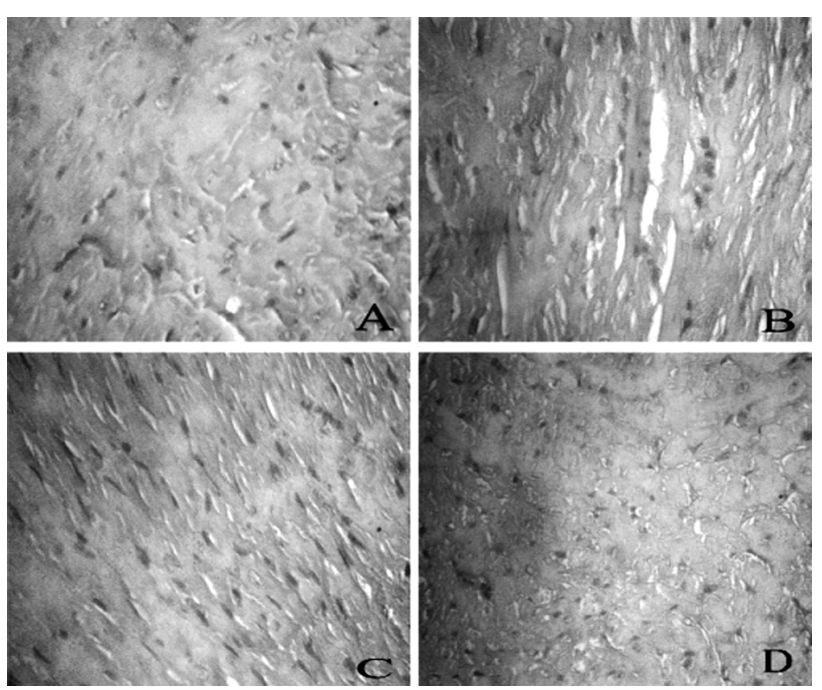

Figure 5. Histopathology. Representative sections of heart tissue of tumor bearing mice (A) untreated (B) DOX $25 \mathrm{mg} / \mathrm{kg}$ (C) DOX+FA $100 \mathrm{mg} / \mathrm{kg}$ and (D) DOX+FA $200 \mathrm{mg} / \mathrm{kg}$

\subsection{Morphological Study}

Histopathological examination of the heart tissues of normal animals showed clear integrity of myocardial cell membrane (Fig. 5 A), and no inflammatory cell infiltration was seen. Light microscopic examination of hearts stained with hematoxylin and eosin of the control and FA-treated animals displayed a normal morphological appearance. Whereas the hearts of the DOX-treated animals showed myocardial degeneration including the loss of myofibrils, focal cytoplasmic vacuolization and endocardium appear disrupted in some places (Fig. 5 B). In tumor bearing mice treated with FA and DOX, a significant reduction in the severity of myocardial degeneration was observed (Fig. 5 C and D).

The histopathological examination of tumor tissues is detailed in the figure 6 . Tumor tissues of control animals showed compact arrangement of carcinomatous cells having clear cytoplasm and hyperchromatic nuclei. Whereas the DOX treated animals showed many degenerating cells, stroma showed extensive areas of necrosis and haemorrhage. Tumor bearing animals administered with FA and DOX, showed a significant increase in the number of degenerating cells. Stroma showed extensive areas of necrosis, cellular integrity was lost in many regions. The results showed that FA potentiates the cytotoxic action of doxorubicin in tumor cells.

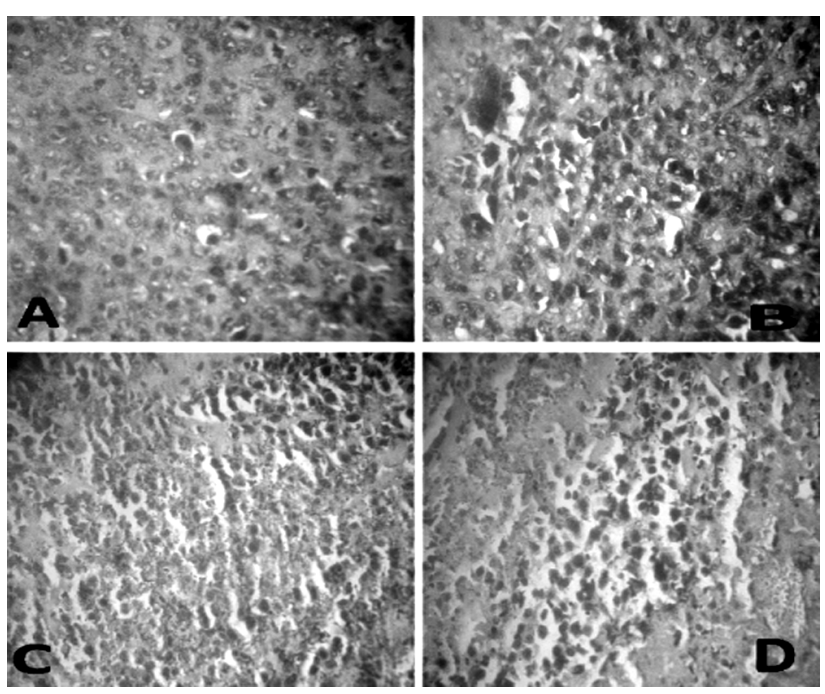

Figure 6. Histopathology. Representative sections of tumor tissue of tumor bearing mice (A) untreated (B) DOX $25 \mathrm{mg} / \mathrm{kg}$ (C) DOX+FA 100 $\mathrm{mg} / \mathrm{kg}$ and (D) DOX+FA $200 \mathrm{mg} / \mathrm{kg}$

\subsection{Estimation of Cellular DNA Damage in Heart and Tumor Tissues of Tumor Bearing Mice}

The administration of DOX caused damage to the cellular DNA in both tissues such as heart (Fig. 7) and tumor (Fig. 8) as evident from the increase in the comet parameters. In heart tissues, tail DNA \%, tail length, tail moment and Olive tail moment were increased from $3.51 \pm 0.67,3.30 \pm 0.79$, $0.20 \pm 0.06$ and $0.23 \pm 0.09$ to $8.15 \pm 1.52,8.61 \pm 1.83,1.19 \pm 0.19$, 
$0.95 \pm 0.11$ in the control DOX- treated group. When 100 $\mathrm{mg} / \mathrm{kg}$ body weight of FA was administered orally one $\mathrm{hr}$ after DOX-administration, there was significant decrease in the comet parameters in heart tissue, as can be seen in Fig.7. The parameters such as \% DNA in tail, tail length, tail moment and olive tail moment were brought down to levels of $6.13 \pm 0.62,6.37 \pm 1.11,0.90 \pm 0.25$ and $0.76 \pm 0.15$ respectively $(\mathrm{P}<0.001)$. While, $200 \mathrm{mg} / \mathrm{kg}$ body weight of FA significantly decreased the comet parameters to $4.58 \pm 0.34$, $3.51 \pm 0.89,0.45 \pm 0.16$ and $0.46 \pm 0.12$ showing cardio protection $(\mathrm{P}<0.001)$. The results clearly indicated the ability FA to offer protection to cellular DNA against DOX- induced cardiomyopathy.

In tumor tissues, administration of DOX caused DNA damage and percentage DNA in tail, tail length, tail moment and Olive tail moment were increased from $4.47 \pm 0.90,3.50$ $\pm 1.02,0.16 \pm 0.02$ and $0.26 \pm 0.06$ to $5.39 \pm 0.79,5.94 \pm$ $0.52,1.37 \pm 0.12$ and $0.96 \pm 0.25$ in the DOX treated group (Fig.8). The comet parameters like tail DNA \%, tail length, tail moment and Olive tail moment were increased to $6.13 \pm$ $0.35,6.8 \pm 0.24,1.68 \pm 0.09$ and $1.93 \pm 0.15$ in the DOX with FA (100 mg/kg body weight) treated group. When $200 \mathrm{mg} / \mathrm{kg}$ body weight of FA along with DOX significantly enhanced the comet parameters to $7.55 \pm 0.11,7.66 \pm 0.05,1.92 \pm 0.08$ and $1.93 \pm 0.15$ showing the antitumor activity of FA.

\section{Discussion}

Several studies have demonstrated the generation of a cascade of reactive oxygen species (ROS) such as $\mathrm{O}_{2}^{-}, \mathrm{OH}$ and $\mathrm{H}_{2} \mathrm{O}_{2}$, which are implicated in the DOX- induced cardiotoxicity[23,24]. The semiquinone form, produced by the reduction of DOX by several endogenous enzymes, generates $\mathrm{O}_{2}-$ radical by transferring electrons to molecular oxygen. The superoxide radicals are rapidly transformed, either
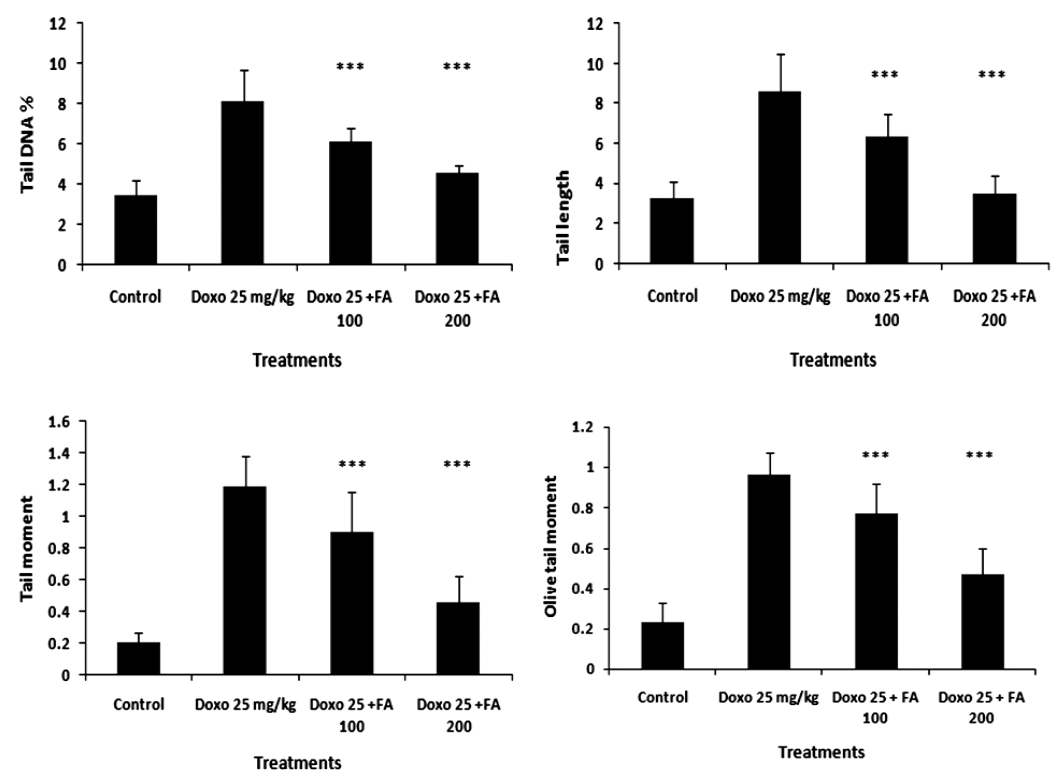

spontaneously or enzymatically, into other forms of ROS such as $\cdot \mathrm{OH}$ and $\mathrm{H}_{2} \mathrm{O}_{2}$ [25]. Among the postulated mechanisms of doxorubicin cardiomyopathy, include radical formation with lipid peroxidation, depletion of cardiac reduced glutathione, inhibition of cardiac coenzyme $\mathrm{Q}_{10}$ and a decrease in cardiac adenylate charge. A number of measures to protect against cardiomyopathy have been investigated. Of these, the most encouraging ones are concurrent administration of vitamin $\mathrm{E}$, coenzyme $\mathrm{Q}_{10}, \mathrm{~N}$-acetylcysteine, cysteamine, razoxane (ICRF 159) and its isomer, ICRF 187, and administration of doxorubicin by continuous intravenous infusion or within liposomal carriers[26].

The results of the present study indicate that i.p injection of DOX at a dose of $25 \mathrm{mg} / \mathrm{kg} \mathrm{b}$.w, induced oxidative stress in cardiac tissues as manifested by elevated serum LDH and CK levels. These enzymes are mostly considered as important markers of early and late cardiac injury especially during clinical follow-up of doxorubicin therapy. Many previous studies have demonstrated similar elevations in cardiac enzymes activities in rats following challenge with a single cumulative dose of doxorubicin[27-30]. Administration of FA, significantly protected mice from DOX-induced elevated levels of LDH and CK. The levels of serum SGOT and SGPT were also elevated in DOX treated animals and administration of FA significantly reversed the levels of these enzymes when compared to DOX alone treated control animals. The increased elevation of SGOT and SGPT levels in serum could result from tumor cell production and therefore be a tumor marker. The elevated SGOT and SGPT levels indicate abnormal liver function secondary to tumor growth[31]. Increase in the level of HDL indicates that doxorubicin may be interfering with metabolism or biosynthesis of lipids[32]. Post-treatment with FA following DOX administration showed significant increase in HDL cholesterol.

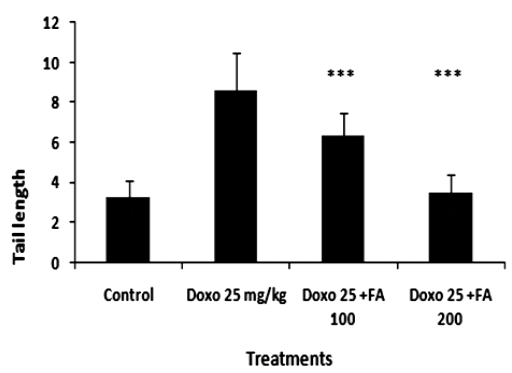

Figure 7. Effect of Ferulic acid $(100 \mathrm{mg} / \mathrm{kg}$ and $200 \mathrm{mg} / \mathrm{kg})$ on DNA damage in mice cardiomyocytes induced by administration of doxorubicin $(25 \mathrm{mg} / \mathrm{kg})$ assessed by comet assay. Percentage DNA in tail, tail length, tail moment and olive tail moment is presented as mean \pm sd (*** indicate $\mathrm{p}<0.001$ when compared with DOX alone treated group) 

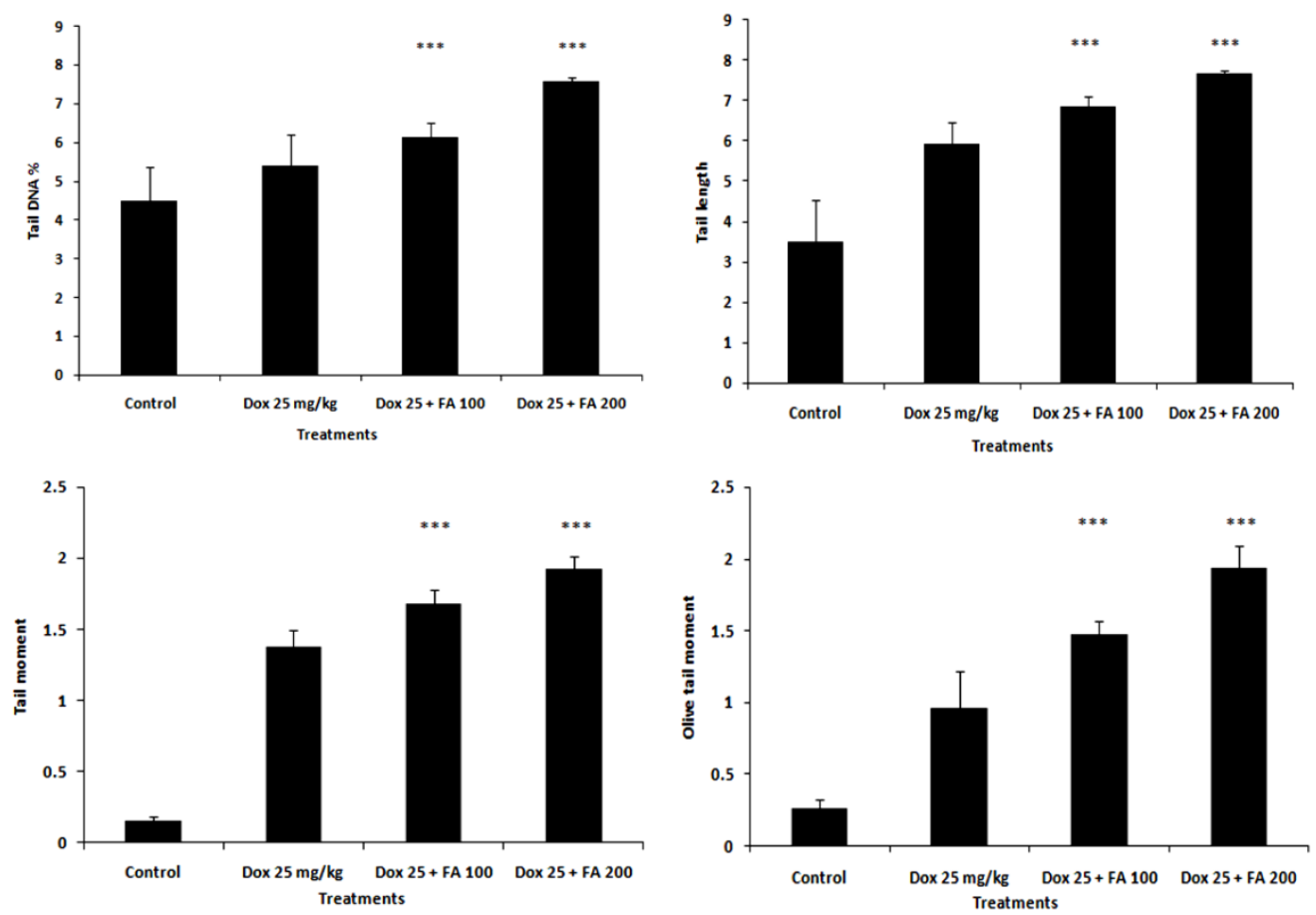

Figure 8. Effect of Ferulic acid (100 mg/kg and $200 \mathrm{mg} / \mathrm{kg})$ on DNA damage in tumor tissues of tumor bearing mice induced by administration of doxorubicin $(25 \mathrm{mg} / \mathrm{kg})$ assessed by comet assay. Percentage DNA in tail, tail length, tail moment and olive tail moment is presented as mean $\pm \mathrm{sd}(* * *$ indicate $\mathrm{p}<0.001$ when compared with DOX alone treated group)

Doxorubicin administration induced oxidative stress in cardiac tissues as manifested by the alterations observed in cardiac antioxidant defense systems both enzymatic and non-enzymatic. From the present study, it is clear that DOX significantly reduced the cardiac GSH content, besides it notably lowered the cardiac enzymatic activities of SOD and GPx associated with a marked increase in cardiac lipid peroxidation as manifested by increased MDA level. Administration of both the doses of $100 \mathrm{mg} / \mathrm{kg}$ and $200 \mathrm{mg} / \mathrm{kg}$ of FA inhibited the DOX induced consequences and significantly increased the antioxidant enzymes SOD and GPx. In addition, the enhancement in cardiac GSH status and decrease in tissue MDA levels, indicated a significant reduction in the extent of cellular oxidative damage by FA. Moreover the histopathological reports suggest that post-treatment of FA greatly inhibited the DOX induced changes in cardiac tissue supporting the protective action of FA against DOX induced cardiotoxicity.

The induction of oxidative damage by DOX results in extensive damage to cellular DNA as revealed in comet assay. Here, a greater portion of DNA has fragmented and migrated sufficiently to make the long tail. Due to severe myocardial infarction the cellular DNA undergoes damage, as reflected in the increase in comet parameters (tail length, \% DNA in tail, tail moment and olive tail moment) in DOX treated groups. Post administration of FA decreased the comet parameters indicative of its protecting ability.

A main prerequisite for any compound to be used as a cardioprotective agent during the treatment of cancer is that it should not interfere with the antitumor activity of the chemotherapy. Several studies in animals and humans con- firmed that FA demonstrates anticancer properties[33,34]. The MDA levels of tumor tissues in FA and DOX treated animals showed an increase in the level when compared to the untreated control animals. The antioxidant levels in tumor tissues were also found to be significantly reduced by the administration of doxorubicin and ferulic acid. The comet assay analysis showed that DNA damage was significantly enhanced in the tumor tissues revealing the antitumor potential of the combination treatment.

\section{Conclusions}

Administration of Ferulic acid after DOX treatment in tumor bearing Swiss albino mice restored all the biochemical parameters altered by this cytotoxic anticancer drug to near normal levels in the cardiac tissue. FA prevented the DOX induced myocardial toxicity by boosting the endogenous antioxidant activity, lowering the cardiac biomarker enzymes (CK and $\mathrm{LDH})$ and preventing the degeneration of cardiac tissue. Further, the combination treatment showed greater antitumor activity as seen from the antioxidant enzyme levels, extent of membrane lipid peroxidation, DNA damage (comet assay) and histopathological analysis. The combined treatment of DOX and FA holds promise as a safe and effective chemotherapeutic strategy.

\section{ACKNOWLEDGEMENTS}

The authors express their gratitude to the Kerala State Council for Science Technology and Environment 
(KSCSTE), Govt. Kerala, Trivandrum, India for the financial support as a research grant to CKKN and CSIR, Government of India for JRF grant awarded to SCAD.

\section{REFERENCES}

[1] P K Singal and N Iliskovic., 1998, Doxorubicin-induced cardiomyopathy., N Engl J Med., 339, 900-905.

[2] D D Von Hoff, M W Layard and Basa P., 1979, Risk factors for doxorubicin-induced congestive heart failure. Ann Intern Med, 91, 710-7.

[3] C F Myers, W P Mc Guire and R H liss., 1977, Adriamycin. The role of lipid peroxidation in cardiotoxicity and tumor response. Science., 197, 165-167.

[4] C C Bier and R S Jaenke., 1976, Function of myocardial mitochondria in the Adriamycin induced cardiomyopathy of rabbits. J Natl Cancer Inst., 57, 1091-4.

[5] A Geetha and C S Devi., 1992, Effect of doxorubicin on heart mitochondrial enzymes in rats: A protective role for alpha tocopherol. Indian J exp Biol., 30, 615-8.

[6] J H Doroshow., 1991, Doxorubicin-induced cardiac toxicity. N Engl J Med., 324, 843-845.

[7] M F Xu, P L Tang, Z M Qian and M Ashraf., 2001, Effects by doxorubicin on the myocardium are mediated by oxygen free radicals. Life Sci., 68, 889-901.

[8] M A Abou-El-Hassan, M J Rabelink, W J van der Vijgh, A Bast and RC Hoeben., 2003, A comparative study between catalase gene therapy and the cardioprotector monohydroxyethylrutoside (MonoHER) in protecting against doxorubicin-induced cardiotoxicity in vitro. Br J Cancer., 89, 2140-6.

[9] X Liu, Z Chen, CC Chua, Y Ma, GA Youngberg, R Hamdy and BHL Chua., 2002, Melatonin as an effective protector against Doxorubicin induced cardiotoxicity. Americ J Physiol Heart and Circulatory Physiol., 283, H254-H263.

[10] Nakagawa and Yokozawa T., 2002, Direct scavenging of nitric oxide and superoxide by green tea. Food Chem. Toxicol., 40, 1745-50.

[11] E Graf., 1992, Antioxidant potential of ferulic acid. Free Radical Biol Med., 13, 435-48.

[12] W Kuenzig, J Chau, E Norkus, H Holowaschenko, H Newmark, W Mergens and A H Conney., 1984, Caffeic and ferulic acid as blockers of nitrosamine formation. Carcinogenesis., 5, 309-313.

[13] M Sreenivasan, AR Sudheer and VP Menon., 2007, Ferulic acid : Therapeutic Potential Through its antioxidant property. Recent Advances In Indian Herbal Drug Research. J. Clin. Biochem Nutr., 40, 92-100.

[14] DK Maurya, VP Salvi and CKK Nair., 2005, Radiation protection of DNA by ferulic acid under in vitro and in vivo conditions. Mol Cell Biochem., 280, 209-17.

[15] JM Mc Cord and I Fridovich., 1969, Superoxide dismutase enzyme function for erythrocuprein (hemocuprein). J Bio Chem., 244, 6049-6055.
[16] DG Hafemann, RA Sunde and WG Hoekstra., 1974, Effect of dietary selenium on erythrocyte and liver glutathione peroxides in the rat. J Nutr., 104, 580-587.

[17] M S Moron, JN De Pierre and V Mannervik., 1979, Levels of glutathione glutathione reductase and glutathione S-transferase activities in rat lung and liver. Biochim Biophys Acta., 582, 67-78.

[18] A J Buege and S D Aust., 1978, Microsomal Lipid Peroxidation. Methods Enzymol., 52, 302-10.

[19] DK Chandrasekharan, VT Kagiya and CKK Nair., 2009, Radiation protection by 6- palmitoyl ascorbic acid2-glucoside: studies on DNA damage in vitro, ex vivo, in vivo and oxidative stress in vivo. J Radiat Res., 50, 203-12.

[20] H Cerda, H Delincee, H Haine and H Rupp., 1997, The DNA 'Comet Assay' as a Rapid Screening Technique to Control Irradiated Food. Mutat Res /Fundam Mol Mech Mugag., 375, 167-81.

[21] K Konca, A Lankoff, A Banasik, H Lisowka, T Kuszewski, S Gozdz, Z Koza and A Wojcik., 2003, Across Platform Public Domain PC Image Analysis Programme for the Comet Assay. Mutat Res., 534, 15-20.

[22] D Sandeep and CKK Nair., 2010, Protection of DNA and membrane from $\gamma$-radiation induced damage by the extract of Acorus calamus Linn.: an in vitro study. Environ Toxicol Pharmacol., 29, 302-307.

[23] S V Kalivendi, S Kotamraju, H Zhao, J Joseph and Kalyanaraman B., 2001, Doxorubicin-induced apoptosis is associated with increased transcription of endothelial nitric-oxide synthase. Effect of antiapoptotic antioxidants and calcium. $J$ Of Biol Chem., 276, 47266-47276.

[24] S Wang, EA Konorev S, Kotamraju, J Joseph, S Kalivendi and B Kalyanaraman., 2004, Doxorubicin induces apoptosis in normal and tumor cells via distinctly different mechanisms. intermediary of $\mathrm{H}(2) \mathrm{O}(2)$ - and p53-dependent pathways. $J O f$ Biol Chem., 279, 25535-25543.

[25] V Lee, A K Randhawa and P K Singal., 1991, Adriamycin-induced myocardial dysfunction in vitro is mediated by free radicals. Am J Of Physiol., 261, H989-H995.

[26] E Saltiel and Wv McGuire., 1983, Doxorubicin (Adriamycin) cardiomyopathy (Medical Progress). West J of Med, 139, 332-341.

[27] M Yagmurca, E Fadillioglu, H Erdogan, M, S Ucar Sogut and M K Irmak., 2003, Erdosteine prevents doxorubicin induced cardiotoxicity in rats. Pharmacol Res., 48, 377-382.

[28] M N Nagi and M A Mansour., 2000, Protective effect of thymoquinone against Doxorubicin-induced cardiotoxicity in rats: a possible Mechanism of protection. Pharmacol Res., 41, 283-9.

[29] P Ragavendran, D Sophia, C Arulraj and V K Gopalakrishnan., 2012, Cardioprotective effect of aqueous, ethanol and aqueous ethanol extract of Aerva lanata (Linn.) against doxorubicin induced cardiomyopathy in rats. Asian Pac J Trop Biomed., 1-7.

[30] T Vijay, M S D Rajan, K Sarumathy, S Palani and K Sakthivel., 2011, Cardioprotective, antioxidant activities and phytochemical analysis by GC-MS of Gmelina arborea (GA) in doxorubicin-induced myocardial necrosis in Albino rats. $\mathrm{J}$ 
Appl Pharm Sci. 01 (05), 198-204.

[31] MB Popp, AK Kirkemo, S D Morrison and MF Brennan., 1984, Tumor and host carcass changes during total parenteral nutrition in an anorectic rat-tumor system. Ann Surg., 199, 205-210.

[32] BC Koti, A H M Vishwanathswamy, J Wagawade and A H M Thippeswamy., 2009, Cardioprotective effect of lipistat against doxorubicin induced myocardial toxicity in albino rats. Indian J of Exp Biol., 47, 41-46.
[33] M Asanoma, K Takahashi, M Miyabe, K Yamamoto, N Yoshimi, H Mori and Y Kawazoe., 1994, Inhibitory effect of topical application of polymerized ferulic acid, a synthetic lignin, on tumor promotion in mouse skin two stage tumorigenesis. Carcinogenesis., 15, 2069-71.

[34] Lesca P., 1983, Protective effects of ellagic acid and other plant phenols on benzo[a] pyrene-induced neoplasia in mice. Carcinogenesis., 4, 1651-1653 